\title{
Pendidikan Berbasis Keunggulan Lokal pada Madrasah Tsanawiyah di Kota Mataram
}

\author{
M. Zaki \\ Universitas Islam Negeri Mataram, Nusa Tenggara Barat, Indonesia \\ email:amakikaz02@gmail.com
}

\begin{abstract}
This study aims to describe in detail and analyze in depth the process of determination, forms of community participation, and implementation of local excellence education in tsanawiyah madrasas in the city of Mataram. The research method used is qualitative descriptive type. Data collection uses participatory observation techniques, in-depth interviews and documentation. Data analysis procedures rely on the narrative descriptive model ala Miles and Huberman in the form of data reduction, data presentation and verification. Based on data analysis, the results of the research can be described in the form of: (1) The process of determining local excellence into local excellence education is carried out through meetings, socialization, questionnaire distribution, and determination; (2) The form of limited community participation as teaching staff and trainers, does not involve relevant agencies, and traditional institutions in the community; and (3) Local excellence education is implemented through extracurricular activities in the form of rudat dance, and grouped into Art and Culture subjects in the form of music, especially sound art (Sasak regional songs). In addition to the results, this study also found that local excellence of rudat art does not have curriculum guidance, the process is direct to practice, and does not have assessment instruments. While local excellence through the subject of Arts and Culture uses the RPP tool downloaded from the internet, and does not make adjustments to the local excellence needs of the local area.

Keywords: Local Excellence Education, Determination, Community Participation, and Implementation of Local Excellence Education

\begin{tabular}{|c|c|c|}
\hline $\begin{array}{c}\text { First Receive: } \\
\text { 4 October 2019 }\end{array}$ & $\begin{array}{c}\text { Revised: } \\
\text { 26 October 2019 }\end{array}$ & 5 November 2019 \\
\hline $\begin{array}{c}\text { Final Proof Recieved: } \\
\text { 11 November 2019 }\end{array}$ & Published: \\
\hline \multicolumn{3}{|c|}{ 21 December 2019 } \\
$\begin{array}{c}\text { Zaki, M., (2019). Pendidikan Berbasis Keunggulan Lokal pada Madrasah Tsanawiyah } \\
\text { di Kota Mataram. Schemata, 8 (2), 21-33. }\end{array}$ \\
\hline
\end{tabular}
\end{abstract}

\section{PENDAHULUAN}

Selain sebagai pusat pemerintahan dan pendidikan, Kota Mataram juga merupakan salah satu destinasi wisata yang menarik untuk dikunjungi baik oleh wisatawan domestik maupun manca negara. Posisi yang strategis ini membuatnya tidak dapat berkelit dan menghindar dari berbagai pengaruh budaya asing. Realitas ini akan berdampak pada pergeseran nilai budaya yang dimiliki dan diyakini oleh masyarakat. Apabila hal ini tidak diantisipasi, dipastikan nilai-nilai budaya lokal yang telah dimiliki akan tercabut, terancam punah, dan akan ditinggalkan serta digantikan dengan budaya lain. Itulah mengapa, generasi muda yang tumbuh dan berkembang di Kota Mataram, niscaya dibekali dengan berbagai pengetahuan, keterampilan dan nilai-nilai kehidupan yang berakar dan bersumber dari nilai- 


\section{Zaki, Pendidikan Berbasis Keunggulan Lokal pada Madrasah Tsanawiyah di Kota Mataram}

nilai budaya lokal, sehingga kekayaan budaya serta keunggulan dan keunikan yang dimiliki oleh daerah ini dapat dilestarikan. Pemerintah melalui lembaga pendidikan, memberikan kesempatan kepada sekolah atau madrasah untuk meneruskan nilai-nilai budaya, baik lokal maupun nasional kepada para peserta didik melalui kegiatan pendidikan berbasis keunggulan lokal.

Implementasi pendidikan berbasis keunggulan lokal di sekolah atau madrasah tertuang dalam Undang-Undang RI Nomor 20 Tahun 2003 tentang Sistem Pendidikan Nasional bab XIV pasal 50 ayat 5 menegaskan bahwa: "pemerintah Kabupaten/Kota mengelola pendidikan dasar dan menengah, serta satuan pendidikan yang berbasis pendidikan lokal". ${ }^{21}$ Pada tataran praksis, norma ini diwejantahkan melalui Peraturan Pemerintah RI Nomor 19 Tahun 2005 bab III pasal 14 ayat 1: "kurikulum untuk SMP/MTs/SMPLB atau bentuk lain yang sederajat dan kurikulum untuk SMA/MA/SMALB atau bentuk lain yang sederajat dapat memasukkan pendidikan berbasis keunggulan lokal". ${ }^{22}$

Pendidikan berbasis keunggulan lokal diandaikan sebagai pendidikan yang memanfaatkan keunggulan lokal dalam aspek ekonomi, seni budaya, sumber daya manusia, bahasa, teknologi informasi dan komunikasi, ekologi dan lainnya ke dalam kurikulum sekolah yang akhirnya bermanfaat bagi pengembangan kompetensi peserta didik. ${ }^{23}$ Tujuan penyelenggaraan pendidikan berbasis keunggulan lokal adalah agar peserta didik mengetahui keunggulan lokal daerah dimana dia tinggal, memahami berbagai aspek yang berhubungan dengan keunggulan lokal daerah tersebut, selanjutnya peserta didik mampu mengolah sumber daya dan terlibat dalam pelayanan jasa atau kegiatan lain yang bertalian dengan keunggulan lokal sehingga memperoleh pendapatan dan melestaraikan budaya, tradisi, sumber daya yang menjadi unggulan daerah serta mampu bersaing secara nasional dan global. ${ }^{24}$

Sementara itu, ruang lingkup pendidikan berbasis keunggulan lokal meliputi lingkup situasi dan kondisi daerah, serta lingkup keunggulan lokal. Lingkup situasi dan kondisi daerah yaitu segala sesuatu yang terdapat di daerah tersebut yang bertalian dengan

${ }^{21}$ Undang-Undang RI Nomor 20 Tahun 2003 tentang Sistem Pendidikan Nasional, (Bandung: Citra Umbara, 2012), h. 174.

22Peraturan Pemerintah Nomor 19 Tahun 2005 tentang Standar Nasional Pendidikan, Jakarta, Sinar Grafika, 2015), h. 67.

23Jamal Ma'mur Asmani, Pendidikan Berbasis Keunggulan Lokal, (Yogyakarta: Diva Pres, 2012), 29.

${ }^{24}$ Iif Khoiru Ahmad, Mengembankan Pendidikan Berbasis Keunggulan Lokal dalam KTSP, (Jakarta: Prestasi Pustaka, 2012), 10.

\section{Copyright (C) 2019 Schemata Journal}

Available online at http://journal.uinmataram.ac.id/index.php/schemata 
M. Zaki, Pendidikan Berbasis Keunggulan Lokal pada Madrasah Tsanawiyah di Kota Mataram

lingkungan alam, sosial, ekonomi, seni budaya yang menjadi keunggulan suatu daerah. Sedangkang lingkup keunggulan lokal meliputi potensi keunggulan lokal, cara mengelola, mengolah, mengemas, mengoptimalkan, memasarkan, atau proses lainnya yang mampu menghasilkan nilai tambah bagi daerah sehingga dapat mengingkatkan taraf hidup dan kesejahteraan masyarakat maupun pendapatan daerah. ${ }^{25}$ Ruang lingkup ini meniscayakan sekolah atau madrasah untuk melakukan kajian dan penelitian secara mendalam dan komprehensif dengan metode penelitian yang obyektif dan akuntabel.

Madrasah tsanawiyah sebagai salah satu jenjang pendidikan dasar memiliki tanggung jawab besar membekali peserta didiknya pada berbagai kemampuan. Kemajuan ilmu pengetahuan dan teknologi yang sangat pesat di era globalisasi ini meniscayakan madrasah untuk mampu mempersiapkan peserta didiknya untuk unggul pada dimensi kognitifnya. Dimensi ini penting, mengingat pada era industri 4.0 ini, kompetisi hanya bisa dimenangkan manakala peserta didik memiliki kompetensi yang unggul dalam bidang ilmu pengetahuan dan teknologi. Pada sudut yang lain, kemajuan ilmu pengetahuan dan teknologi dapat menggerus nilai-nilai agama yang galib diyakini dan dipedomani oleh peserta didik mengingat demoralisasi dan desakralisasi nilai-nilai agama dan budaya sedang terjadi bahkan sudah samapai pada titik nadir. Keluarga, masyarakat dan bahkan media telah gagal memberikan proses edukasi yang efektif. Disinilah letak urgensinya dimensi afektif menjadi niscaya bagi sekolah atau madrasah untuk terus membekali peserta didiknya.

'Alakullihal, masyarakat juga menaruh asa yang sangat tinggi bagi sekolah atau madrasah untuk dapat membekali peserta didiknya pada dimensi psikomotorik agar dapat keluar dari jurang kemiskinan dan keterbelakanagan. Pendidikan berbasis keunggulan lokal lebih menekankan dimensi psikomotorik karena dapat membekali peserta didiknya dengan berbagai kemampuan dan keterampilan yang bisa digunakan untuk dapat survive di tengah persaingan yang semakin tajam dan keras. Pendidikan berbasis keunggulan lokal ini juga dapat mendorong masyarakat luas untuk mengembangkan potensi lokalnya menjadi keunggulan lokal yang bisa meningkatkan kesejahteraan hidup.

Madrasas Tsanawiyah (MTs) di Kota Mataram mempunyai tanggung jawab besar dalam mengawal dan mengimplementasikan pendidikan berbasis keunggulan lokal ini secara serius dan optimal supaya mampu menghasilkan proses, hasil serta tindaklanjut yang berkualitas dan berkesinambungan. Itulah mengapa penelitian ini dilakukan dengan

${ }^{25}$ Ibid.

\section{Copyright $@ 2019$ Schemata Journal}

Available online at http://journal.uinmataram.ac.id/index.php/schemata 
M. Zaki, Pendidikan Berbasis Keunggulan Lokal pada Madrasah Tsanawiyah di Kota Mataram

memusatkan perhatian pada proses penetapan, bentuk partisipasi masyarakat, dan implementasi pendidikan keunggulan lokal pada MTs. di Kota Mataram tahun 2018/2019.

\section{METODE PENELITIAN}

Penelitian ini menggunakan metode kualitatif dengan corak deskriptif. Pengenaan metode kualitatif dimaksudkan untuk mempelajari dan mengkaji secara mendalam tentang pendidikan berbasis keunggulan lokal pada madrasah tsanawiyah di Kota Mataram. Melalui metode ini, peneliti memberikan verifikasi yang realistis agar dapat digunakan sebagai bahan evaluasi dan sebagai pijakan dalam mengambil kebijakan mengenai pelaksanaan pendidikan keunggulan lokal pada MTs. di Kota Mataram.

Data dalam penelitian ini dikelompokkan menjadi dua yaitu data verbal dan data non verbal (tindakan). Data verbal lisan diperoleh melalui pencatatan dan perekaman hasil wawancara tentang pelaksanaan pendidikan keunggulan lokal pada MTs di Kota Mataram. Data verbal tulisan dapat diperoleh melaui sumber tertulis berupa dokumen baik tertulis tentang pemilihan keunggulan lokal, bentuk partisipasi masyarakat, instansi terkait dan dokumen pengembangan kurikulum serta pelaksanaan pendidikan berbasis keunggulan lokal pada MTs. di Kota Mataram. Sedangkan data non verbal berupa hasil pengamatan dan pencatatan tentang pelaksanaan pendidikan berbasis keunggulan lokal pada MTs. di Kota Mataram tahun 2018/2019.

Sumber data ini dikelompokkan dalam dua bagian yaitu sumber data berupa subyek penelitian dan tempat penelitian. Sumber data berupa subyek penelitian adalah mereka yang secara langsung mengetahui peristiwa terkait dengan pelaksanaan pendidikan berbasis keunggulan lokal pada MTs. di Kota Mataram. Subyek penelitian yang dimaksud adalah kepala dan wakil kepala bidang kesiswaan, guru pembina, tenaga pengajar yang ada di madrasah tsanawiyah. Sedangkan tempat sebagai sumber data adalah lokasi di mana peristiwa pendidikan berbasis keunggulan lokal dilaksanakan yaitu tiga MTs. Negeri dan 6 MTs. Swasta di Kota Mataram.

Pengumpulan data penelitian dibagi dalam tiga tahap, yaitu (1) pralapangan, (2) kegiatan lapangan dan (3) analisis intensif. Tahap kegiatan lapangan; dilakukan melalui, wawancara, pengamatan, dan dokumentasi. Analisis data dilakukan selama dan sesudah pengumpulan data dilakukan. Hal ini mengacu kepada pendapat Miles dan Huberman, ${ }^{26}$

${ }^{26}$ Matthew B. Miles dan A. Michael Huberman, Analisis Data Kualitatif terjemahan Rohidi Tj. R., (Jakarta: Universitas Indonesia, 1992), h. 15-21. 
M. Zaki, Pendidikan Berbasis Keunggulan Lokal pada Madrasab Tsanawiyah di Kota Mataram

bahwa analisis data dalam penelitian kualitatif terdiri dari tiga alur yaitu (1) reduksi data, (2) penyajian data, dan (3) penarikan kesimpulan/verifikasi.

\section{HASIL DAN PEMBAHASAN}

\section{Pemilihan Pendidikan Berbasis Keunggulan Lokal}

Berdasarkan temuan dan analisis data, pemilihan pendidikan berbasis keunggulan lokal pada MTs. di Kota Mataram dilakukan melalui mekanisme rapat dewan guru. Dalam forum rapat ini, berbagai gagasan dan bentuk keunggulan lokal diusulkan oleh peserta rapat. Usulan-usulan tersebut identifikasi dan didiskusikan secara serius untuk mengetahui peluang dan tantangannya. Selanjutnya para guru menyepakati bentuk-bentuk keuanggulan lokal yang akan diimplemetasikan. Namun demikian, kesepakatan dalam forum rapat ini ditawarkan kepada peserta didik untuk memilih sesuai dengan minatnya. Proses penentuan dengan memberikan kesempatan kepada peserta didik untuk memilih merupakan salah satu bentuk pelibatan peserta didik. Bagian ini merupakan salah satu proses need assessment dengan menggunakan instrumen seperti angket, wawancara maupun diskusi. Proses di dalam penentuan keunggulan lokal di madrasah Kota Mataram belum seluruhnya dilaksanakan oleh madrasah, sebagaimana yang diidealkan oleh Ahmadi dalam langkah-langkah mengajukan pengembangan keunggulan lokal di sekolah atau madrasah, antara lain: ${ }^{27}$

a. Mengidentifikasi keadaan dan kebutuhan daerah.

b. Menentukan fungsi dan susunan kompetensi keunggulan lokal.

c. Mengidentifikasi bahan kajian keunggulan lokal.

d. Menentukan mata pelajaran keunggulan lokal.

e. Mengembangkan standar kompetensi dan kompetensi dasar serta silabus dengan mengacu pada Standar Isi yang ditetapkan BNSP.

Langkah awal berupa mengidentifikasi keadaan dan kebutuhan daerah belum pernah dilaksanakan, termasuk mengidentifikasi bahan kajian keunggulan lokal. Dengan cara-cara penentuan keunggulan lokal yang selama ini dilaksanakan di madrasah memungkinkan kontinuitas pelaksanaan pendidikan keunggulan lokal di madrasah tidak dapat terselenggara dengan baik. Cennamo dan Kalk menyatakan bahwa "in the needs assessment the instructional designer identifies the gap between current state of

${ }^{27}$ Iif Khoiru Ahmadi, Mengembangkan.... h. 10 
M. Zaki, Pendidikan Berbasis Keunggulan Lokal pada Madrasah Tsanawiyah di Kota Mataram

affairs and the ideal situation, with the resulting gap representing the need". ${ }^{28}$ Bahwa dalam menilai kebutuhan perlu mengidentifikasi kesenjangan yang terjadi antara peristiwa saat ini dengan keadaan ideal atau yang seharusnya. Suparman juga menyatakan bahwa "kebutuhan adalah kesenjangan keadaan saat ini dibandingkan dengan keadaan yang seharusnya". ${ }^{29}$ Berdasarkan temuan data yang telah dipaparkan, langkah penetapan keunggulan lokal oleh madrasah sangat sederhana yang dapat digambarkan sebagai berikut:

Rapat/Diskusi $\Rightarrow \quad \Rightarrow \quad \Rightarrow \quad$ Menetapkan

\section{Bentuk Partisipasi Masyarakat dalam Pendidikan Berbasis Keunggulan Lokal}

Partisipasi masyarakat dalam penentuan pendidikan berbasis keunggulan lokal pada MTs. di Kota Mataram hanya terbatas sebagai tenaga pengajar atau pelatih. Tidak ditemukan data tentang partisipasi masyarakat dalam bentuk lain, misalnya dalam proses perencanaan, penentuan konten pembelajaran dan lainnya. Minimnya partisipasi masyarakat dalam keseluruhan proses pendidikan berbasis keunggulan lokal ini disebabkan oleh kurangnya komunikasi antara pihak madrasah dengan steakholders. Penting diingat bahwa keberhasilan pendidikan, termasuk pendidikan berbasis keunggulan lokal, salah satunya ditentukan oleh partisipasi masyarakat dalam keseluruhan proses, mulai dari perencanaan, pelaksanaan dan evaluasinya.

Mengingat pentingnya partisipasi masyarakat dalam pendidikan berbasis keunggulan lokal ini, idealnya pelibatan masyarakat dalam arti luas harus dimulai sejak melakukan identifikasi terhadap keunggulan lokal. Masyarakat termasuk orang tua peserta didik, instansi terkait, tokoh masyarakat, organisasi yang mewakili lembaga sosial kemasyarakatan tertentu penting diikutsertakan. Idealisasi ini, senada dengan apa yang diabstraksikan oleh Siri bahwa keberhasilan pendidikan berkaitan langsung dengan keterlibatan dan peran masyarakat lokal. Dengan demikian keefektifan proses pembelajaran terkait dengan keunggulan lokal sangat penting keterkaitan dengan pemimpin komunitas lokal, organisasi yang representatif, dan memerlukan kerjasama dengan perusahaan terkait. ${ }^{30}$

\footnotetext{
${ }^{28}$ Katherine Cennamo \& Debby Kalk, Real Word Instructionanl Design (Australia, Canada, Mexico, Singapore, Spain, United Kingdom, United State, Thomson Wadsworth, 2005), h. 22

${ }^{29}$ Atwi Suparman, Desain Instruksional, (Jakarta, Pusat Penerbitan Universitas Terbuka, 2011), h. 73

${ }^{30}$ Raktida Siri, Lokal Community Participatory Learning with a Nature Interpretation System: A Case Study in Bang Pong, Sansai District, Chiang Mai, Thailand, Kasetrart Journal of Sosial Science, Vol. 38, 2017, h. 181-185.
}

\section{Copyright $\odot 2019$ Schemata Journal}

Available online at http://journal.uinmataram.ac.id/index.php/schemata 


\section{Zaki, Pendidikan Berbasis Keunggulan Lokal pada Madrasab Tsanawiyah di Kota Mataram}

Penetapan keunggulan lokal pada MTs. di Kota Mataram belum sejauh itu dilakukan. Masyarakat secara luas tidak banyak dilibatkan. Jika masyarakat secara luas dapat berpartisipasi dalam penetapan keunggulan lokal, maka dimungkinkan pendidikan di madrasah akan mencerminkan pendidikan yang berbasis kepada masyarakat. Madrasah akan menemukan berbagai kekhasan pendidikan yang diwarnai oleh berbagai potensi keunggulan lokal. Dengan demikian pendidikan berbasis masyarakat yakni pendidikan berdasarkan kekhasan agama, sosial, budaya, aspirasi, dan potensi masyarakat sebagai perwujudan pendidikan dari, oleh, dan untuk masyarakat.

Partisipasi masyarakat hanya sebagai tenaga pengajar merupakan partisipasi sangat terbatas, sehingga madrasah tidak membuka ruang yang cukup untuk masyarakat berkontribusi dalam pendidikan. Masyarakat yang terlibat seharusnya menjadi salah satu bentuk partisipasi masyarakat dalam penentuan pendidikan berbasis keunggulan lokal pada MTs. di Kota Mataram melalui pendekatan partisipatif, dimana masyarakat khususnya orang tua peserta didik diberi kesempatan seluas-luasnya untuk ikut urun rembug masalah pendidikan. ${ }^{31}$

\section{Implementasi Pendidikan Berbasis Keunnggulan Lokal}

Pendidikan berbasis keunggulan lokal pada MTs. di Kota Mataram terimplementasi ke dalam dua bentuk kegiatan yaitu ekstrakurikuler dan intrakurikuler. Keunggulan lokal yang dilaksanakan melalui kegiatan ekstrakurikuler adalah keunggulan lokal berupa tari rudat. Sedangkan keunggulan lokal dalam bentuk kegiatan intrakurikuler dikelompokkan ke dalam mata pelajaran Seni Budaya, berupa lagu-lagu daerah Sasak.

Implementasi pendidikan keunggulan lokal melalui kegiatan ekstrakurikuler tidak didasarkan pada kurikulum. Madrasah, pembina maupun tenaga pengajar tidak melakukan pengembangan kurikulum sebagai pedoman dalam melaksanakan pendidikan berbasis keunggulan lokal. Selain itu, implementasi pendidikan berbasis keunggulan lokal melalui kegiatan ekstrakurikuler ini tidak diikuti dengan penyajian materi berupa konsep, prinsip, prosedur keunggulan lokal yang dipelajari (tari rudat). Akan tetapi pengajar atau pelatih langsung menggunakan metode demosntrasi dan

\footnotetext{
${ }^{31}$ Hasbullah, Otonomi Pendidikan Kebijakan Otonomi Daerah dan Implikasinya terhadap Penyelenggaraan Pendidikan, (Jakarta: Raja Grafindo Persada, 2010), h. 58
} 
M. Zaki, Pendidikan Berbasis Keunggulan Lokal pada Madrasab Tsanawiyah di Kota Mataram

praktek untuk mengajarkan tentang berbagai gerakan dalam tari rudat. Pengajar atau pelatih juga tidak melakukan kajian terhadap bahan yang akan disajikan.

Pembina dan tenaga pengajar semestinya dapat melakukan kajian terhadap lingkungan untuk memperkaya materi keunggulan lokal. Hasil kajian tersebut akan dapat dijadikan pelengkap dalam menyusun bahan pembelajaran berbasis keunggulan lokal. Implementasi pendidikan berbasis keunggulan lokal memiliki banyak potensi sumber daya baik alam maupun manusia untuk dapat dikembangkan sebagai bahan sajian materi. Setiawan mendeskripsikan bahwa modul mata pelajaran berbasis kearifan lokal sangat mungkin untuk dikembangkan karena kesesuaian secara teori dan empiris, dan materi yang diajarkan berhubungan dengan fenomena alam dan ekosistem. ${ }^{32}$

Memperhatikan temuan data penelitian ini dapat disajikan beberapa kelemahan implementasi pendidikan berbasis keunggulan lokal melalui kegiatan ekstrakurikuler pada MTs. di Kota Mataram yaitu:

a. Tidak dimilikinya bahan belajar. Dalam konteks pembelajaran, bahan ajar memiliki kedudukan yang penting dan strategis. Pada umumnya bahan belajar harus disusun untuk memenuhi kebutuhan pembelajaran dalam pendidikan berbasis keunggulan. Bahan pembelajaran tersebut dapat saja bersumber dari bahan cetak maupun non cetak. Yaumi menyatakan bahwa bahan pembelajaran adalah seperangkat bahan yang disusun secara sistematis untuk kebutuhan pembelajaran yang bersumber dari bahan cetak, alat bantu visual, audio, multimedia dan animasi serta komputer dan jaringan. ${ }^{33}$ Dengan demikian menyiapkan dan menyediakan bahan pembelajaran termasuk untuk pendidikan berbasis keunggulan lokal adalah sangat penting baik itu bersumber dari pustaka, media maupun sumber belajar lainnya. Selanjutnya Kanokorn, menyatakan bahwa the important thing included: the preparation for readiness in instructional media, library, and learning source. ${ }^{34}$ Bahan pembelajaran muatan lokal semestinya dapat disusun dan dikembangkan sendiri oleh madrasah, guru pembina atau pengajar karena merekalah yang merupakan faktor utama dalam mengatur isi materi keunggulan lokal yang sesuai dengan

${ }^{32} \mathrm{~B}$. Setiawan, The Development of Lokal Wisdom-Based Natural Science Module to Improve Science Literation of Students, Jurnal Pendidikan IP A Indonesia, Vol. 6 (1), 2017, h. 49-54

${ }^{33}$ Muhammad Yaumi, Prinsip-prinsip Desain Pembelajaran, Jakarta: Kencana Prenada, Media Group, 2013), h. 244

${ }^{34}$ Kanokorn Somprach, Pongtorn Popoonsak, dan Sunjaya Sombatteera, Soft Skills Development to Enhance Teachers Competencies in Primary Schools, Procedia - Sosial and Behavioral Science, 112, 2014 h, 843. 
M. Zaki, Pendidikan Berbasis Keunggulan Lokal pada Madrasab Tsanawiyah di Kota Mataram

kebutuhan peserta didik di wilayah tersebut. Dengan begitu peserta didik akan dapat dengan mudah mengaplikasikan materi tersebut dalam kesehariannya. Sehubungan dengan hal ini Kanokorn juga mengatakan the teacher was a major factor in learning process management for organizing the content material as well as activity to be congruent with students need, practicing their thinking skill, management and application of knowledge in daily life ${ }^{35}$.

b. Tidak dikembangkannya perangkat pembelajaran berupa perencanaan pembelajaran tertulis. Pendidikan berbasis keunggulan lokal Pada MTs. di Kota Mataram ini tidak memiliki silabus, dan rencana pelaksanaan pembelajaran. Perangkat pembelajaran adalah pedoman operasional di dalam penyelenggaraan pendidikan dan pembelajaran. Ia merupakan perencanaan proses pembelajaran berupa seperangkat bahan tertulis yang disiapkan guru sebagai pedoman pembelajaran baik di dalam kelas maupun di luar kelas. Ibrahim dalam Trianto menjelaskan bahwa perangkat pembelajaran dapat berupa "silabus, Rencana Pelaksanaan Pembelajaran (RPP), Lembar Kegiatan Siswa (LKS), instrumen evaluasi atau Tes Hasil Belajar (THB), media pembelajaran, serta buku ajar siswa". ${ }^{36}$

Apabila memperhatikan penjelasan mengenai perangkat pembelajaran di atas, maka implementasi pendidikan berbasis keunggulan lokal di MTs Kota Mataram yang dilaksanakan melalui kegiatan ekstrakurikuler belum dapat dikategorikan sebagai kegiatan pendidikan dan pembelajaran yang baik, mengingat:

1) Penetapan keunggulan lokal terkesan tidak dipersiapkan dengan baik.

2) Madrasah Tsanawiyah di Kota Mataram tidak mengikutsertakan berbagai pihak seperti Kantor Kementerian Agama Kota Mataram, Dinas Pendidikan Kota Mataram, Tim Pengembang Kurikulum Daerah, dan Perguruan Tinggi dalam mendesain pendidikan berbasis keunggulan lokal.

3) Tenaga pengajar atau pelatih tidak berpengalaman sebagai guru, dan atau guru pembina tidak melakukan pendampingan bagi tenaga pengajar dan pelatih keunggulan lokal.

c. Tidak dikembangkannya instrument penilaian dalam proses pendidikan berbasis keunggulan lokal. Penilaian merupakan bagian integeral dari sebuah proses

35 Ibid, h. 84.

36 Trianto, Mendesain Pembelajaran Kontekstual (Contextual Teaching and Learning) di Kelas, (Jakarta, Cerdas Pustaka Publisher, 2008), h. 121. 
pendidikan dan pembelajaran, tidak terkecuali pada pendidikan berbasis keunggulan lokal. Penilaian tidak hanya dimaksudkan untuk mengukur dan mengetahui penguasan peserta didik terhadap kompetensi tertentu, tetapi juga dapat digunakan untuk mengetahui efektifitas proses yang sudah berlangsung. Ibrahim dan Syaodih menyatakan bahwa dua kegunaan mengembangkan instrumen penilaian adalah untuk mengetahui seberapa jauh peserta didik telah menguasai tujuan pelajaran yang telah ditetapkan, dan bagian-bagian mana dari program pengajaran yang masih lemah dan perlu diperbaiki. ${ }^{37}$

Selama penelitian ini dilaksanakan tidak ditemukan dokumen berupa instrumen penilaian yang dikembangkan baik oleh guru pembina maupun oleh tenaga pengajar dan pelatih ekstrakurikuler. Seluruh penilaian dalam implementasi pendidikan berbasis keunggulan lokal ini diserahkan kepada tenaga pengajar dan pelatih, akan tetapi tidak jelas aspek-aspek dan komponen yang dinilai. Jika melihat bentuk kegiatan pendidikan berbasis keunggulan lokal melalui ekstrakurikuler ini, maka penilaian yang lebih banyak dilakukan adalah penilaian melalui pengamatan terhadap keterampilan peserta didik melakukan tari rudat, meskipun tidak boleh mengabaikan penilaian pengetahuan maupun sikap peserta didik.

Penilaian melalui pengamatan ini termasuk dalam penilaian non tes, salah satunya dapat dilakukan melalui pengamatan yakni dengan pengamatan guru pembina atau tenaga pengajar atau pelatih melakukan pengamatan dan pencatatan prilaku, sikap dan keterampilan peserta didik baik secara individu maupun kelompok. Trianto menjelaskan bahwa penilaian pengamatan dipakai untuk menilai minat, sikap dan nilai yang terkandung dalam diri peserta didik. Selain itu dipakai juga untuk melihat proses kegiatan pembelajaran baik individu maupun kelompok." ${ }^{38}$ Implementasi pendidikan berbasis keunggulan lokal melalui kegiatan ekstrakurikuler ini tidak ditemukan instrumen penilaian dalam bentuk apapun baik tes maupun non tes.

Sedangkan pendidikan keunggulan lokal melalu mata pelajaran Seni Budaya, pada perangkat pembelajarannya (RPP) terdapat instrumen penilaian baik untuk penilaian pengetahuan maupun instrumen pengamatan. Akan tetapi instrumen-

${ }^{37}$ R. Ibrahim dan Nana Syaodih, Perencanaan Pengajaran (Jakarta, Rineka Cipta, 2010), h. 86.

${ }^{38}$ Trianto, Desain Pengembangan..., h., 267 
M. Zaki, Pendidikan Berbasis Keunggulan Lokal pada Madrasah Tsanawiyah di Kota Mataram

instrumen tersebut tidak mengarah kepada instrumen yang dapat digunakan untuk mengukur pengetahuan dan keterampilan dalam menampilkan penguasaan keunggulan lokal daerah setempat.

Berdasarkan data penelitian, terdapat beberapa faktor yang menyebabkan tidak dikembangkannya instrumen penilaian dalam pendidikan berbasis keunggulan lokal tari rudat di MTs. Kota Mataram adalah:

a. Guru pembina tidak merumuskan kompetensi dan tujuan pendidikan berbasis keunggulan lokal baik secara umum maupun khusus, sehingga tidak memiliki acuan kompetensi dan tujuan untuk dikembangkan sebagai instrumen penilaian.

b. Guru pembina tidak melakukan pendampingan terhadap tenaga pengajar atau pelatih dalam merencanakan kegiatan pendidikan berbasis keunggulan lokal dalam membuat persiapan kegiatan ekstrakurikuler.

c. Tenaga pengajar atau pelatih tidak memiliki pengetahuan dan pengalaman dalam membuat persiapan sebelum kegiatan pendidikan berbasis keunggulan lokal dilaksanakan.

Berbagai kekurangan dan atau kelemahan dalam implementasi pendidikan berbasis keunggulan lokal melalui kegiatan ekstrakuler yang telah dideskripsikan di atas, dapat disimpulkan bahwa kegiatan pendidikan berbasis keunggulan lokal tari rudat di MTs. Kota Mataram tidak berjalan dengan efektif. Ketidakefektifan dipantik oleh tidak tersedianya berbagai dokumen pembelajaraan yang niscaya dimiliki oleh guru pembina maupun para tenaga pengajar atau pelatih. Membaca realitas ini, tidaklah keliru kalau implementasi pendidikan berbasis keunggulan loka pada MTs. di Kota Mataram dapat disebut gagal. Beberapa fakta di lapangan simpulan ini, antara lain:

a. Pendidikan keunggulan lokal melalui kegiatan ekstrakurikuler tidak berjalan sesuai rencana jadwal yang telah ditetapkan madrasah.

b. MTs. tidak memfasilitasi ketersedian bahan dan alat-alat yang diperlukan dalam melaksanakan proses pendidikan berbasis keunggulan lokal tari rudat.

c. Peserta didik yang berkeinginan meneruskan untuk belajar dan berlatih tari rudat, diberikan kesempatan untuk mengikuti kegiatan tersebut di sanggar rudat yang ada di tempat tinggal mereka.

\section{Copyright $\odot 2019$ Schemata Journal}

Available online at http://journal.uinmataram.ac.id/index.php/schemata 
d. MTs. tidak memiliki hubungan kerjasama dengan instansi terkait seperti Kantor Kementerian Agama Kota Mataram, Dinas Pendidikan Kota Mataram, Lembaga Adat, Dinas Pariwisata, Tim Pengembang Kurikulum Daerah (TPKD), dan Perguruan Tinggi untuk mengembangkan pendidikan berbasis keunggulan lokal.

Pada sudut yang lain, pendidikan keunggulan lokal yang dikelompokkan ke dalam mata pelajaran Seni Budaya, terkesan lebih siap secara administratif. Hal ini terlihat dari jadwal dan perangkat pembelajaran yang dimiliki oleh guru. Akan tetapi perangkat pembelajaran yang digunakan guru mata pelajaran Seni Budaya, hanya berupa rencana pelaksanaan pembelajaran (RPP) saja, tidak dilengkapi dengan silabus. Rencana pembelajaran berupa RPP yang digunakan-pun tidak dikembangkan sendiri oleh guru mata pelajaran Seni Budaya. RPP tersebut diunduh melalui internet, baru kemudian disesuaikan dengan kebutuhan pembelajarkan pendidikan berbasis keunggulan lokal di MTs. Selain itu, RPP yang digunakan dalam pembelajarkan pendidikan berbasis keunggulan lokal, tidak disesuaikan dengan kebutuhan pendidikan berbasis keunggulan lokal setempat (Sasak). Hal ini tampak pada instrumen penilaian yang mengukur kemampuan siswa memberikan contoh lagu-lagu daerah lain (bukan lagu daerah Lombok/Sasak).

Data penelitian di atas mendeskripsikan bahwa guru mata pelajaran Seni Budaya tidak melakukan pengkajian atas bahan pembelajaran yang relevan dengan kebutuhan. Seharusnya guru memperhatikan bahwa keunggulan lokal merupakan kekayaan daerah yang meliputi berbagai potensi daerah baik sumber daya manusia, maupun sumber daya alam. Hal inilah yang diungkapkan oleh Dedidwitagama bahwa keunggulan lokal adalah hasil bumi, kreasi seni, tradisi, budaya, pelayanan jasa, sumber daya alam, sumber daya manusia atau lainnya yang menjadi keunggulan suatu daerah.

Temuan lapangan lainnya diperoleh bahwa meskipun rencana pembelajaran guru tidak dilakukan penyesuaian, dalam pelaksanaan pembelajarannya guru mengajarkan peserta didik menyanyikan lagu-lagu daerah seperti Ngiring Simpang, Berugak Elen, Lalo Ngaro, dan Merariq Kodek. Akan tetapi pelaksanaan pembelajaran ini menjadikan proses tersebut tidak memiliki rencana yang sesuai. Rencana yang ada menjadi kurang termanfaatkan sebagai pedoman, karena dimanfaatkan secara umum saja, bahkan instrumen penilaian tidak relevan dengan materi yang

\section{Copyright $(92019$ Schemata Journal}

Available online at http://journal.uinmataram.ac.id/index.php/schemata 
M. Zaki, Pendidikan Berbasis Keunggulan Lokal pada Madrasah Tsanawiyah di Kota Mataram

dibelajarkan. Pelaksanaannya mengajarkan lagu-lagu daerah Sasak, tetapi instrumen penilaiannya mengukur kemampuan peserta didik mengenal lagu daerah lain (Kalimantan), dan menyanyikan lagu daerah lain (Jaranan). Selain itu nama alat-alat musik yang dikenalkan tertulis dalam RPP, tidak ada satupun nama alat musik daerah di NTB. Di dalam RPP peserta didik dikenalkan dengan alat musik sasando, kecapi, sampek, kolintang, tifa, talempong dan beberapa alat musik lainnya, yang kesemuanya itu adalah alat-alat musik dari daerah lain.

Dengan demikian rencana pembelajaran keunggulan lokal melalui mata pelajaran Seni Budaya tidak relevan dengan kebutuhan lokal, sesuai dengan seni budaya lokal. Selain itu dengan RPP seperti ini akan dapat menyebabkan peserta didik di daerah secara perlahan tidak akan mengenal lagi bahkan tidak mampu menunjukkan keterampilan dalam memainkan musik-musik tradisonal. Penggunaan RPP yang dilakukan oleh guru dengan tidak menyusun dan mengembangkan sendiri tidak sesuai dengan amanah yang tercantum di dalam Permendikbud Nomo 22 Tahun 2016 tentang Standar Proses Pendidikan Dasar dan Menengah yang menyatakan bahwa setiap pendidik pada satuan pendidikan berkewajiban menyusun RPP secara lengkap dan sistematis agar pembelajaran berlangsung secara interaktif, inspiratif, menyenangkan, menantang, efisien, memotivasi peserta didik untuk berpartisipasi aktif, serta memberikan ruang yang cukup bagi prakarsa, kreativitas, dan kemandirian sesuai bakat, minat, dan perkembangan fisik serta psikologis peserta didik. Realitas ini juga mengindikasikan bahwa guru mengabaikan prinsip-

prinsip di dalam penyusunan RPP. Diantara prinsip-prinsip yang harus diperhatikan di dalam menyusun RPP adalah:

1. Perbedaan individual peserta didik.

2. Partisipasi aktif peserta didik.

3. Berpusat pada peserta didik untuk mendorong semangat belajar, motivasi, minat, kreativitas, inisiatif, inspirasi dan kemandirian.

4. Pengembangan budaya membaca dan menulis.

5. Pemberian umpan balik.

\section{KESIMPULAN}

Berdasarkan hasil analisis dan pembahasan data peneltian di atas, dapat ditarik simpulan sebagai berikut:

\section{Copyright $\odot 2019$ Schemata Journal}

Available online at http://journal.uinmataram.ac.id/index.php/schemata 
M. Zaki, Pendidikan Berbasis Keunggulan Lokal pada Madrasah Tsanawiyah di Kota Mataram

1. Proses penetapan pendidikan berbasis keunggulan lokal pada MTs. di Kota Mataram dilaksanakan melalui mekanisme rapat, diskusi, sosialisasi, penyebaran angket kepada peserta didik.

2. Bentuk partisipasi masyarakat dalam pelaksanaan pendidikan berbasis keunggulan lokal pada MTs. di Kota Mataram terbatas sebagai tenaga pengajar dan pelatih. Masyarakat secara luas tidak berpartisipasi sejak proses penetapan, pengembangan bahan belajar, dan pengembangan kurikulum.

3. Implementasi pendidikan berbasis keunggulan lokal dilaksanakan melalui dua kegiatan yaitu kegiatan ekstrakurikuler dan intrakurikuler yang diintegerasikan ke dalam mata pelajaran Seni Budaya. Namun demikian pendidikan berbasis keunggulan lokal melalui kegiatan ekstrakurikuler tidak berjalan efektif dikarenakan beberapa kendala antara lain tidak tersedianya tenaga pengajar dan pelatih tetap, terbatasnya anggaran, tidak memiliki bahan kajian/bahan belajar yang dikembangkan oleh madrasah, tidak dikembangkannya kurikulum keunggulan lokal, tidak memaksimalkan partisipasi masyarakat secara luas baik masyarakat sekitar (wali murid, tokoh agama, tokoh masyarakat), maupun instansi terkait.

\section{DAFTAR PUSTAKA}

Ahmad, I. K (2012). Mengembankan Pendidikan Berbasis Keunggulan Lokal dalam KTSP, Jakarta: Prestasi Pustaka

Asmani, J. M. (2012). Pendidikan Berbasis Keunggulan Lokal, Yogyakarta: Diva Pres.

Hasbullah, (2010). Otonomi Pendidikan Kebijakan Otonomi Daerah dan Implikasinya terhadap Penyelenggaraan Pendidikan, Jakarta: Raja Grafindo Persada.

Ibrahim, R., \& Nana, S., (2010). Perencanaan Pengajaran, Jakarta, Rineka Cipta.

Kanokorn, S., Pongtorn, P., \& Sunjaya, S., (2014) Soft Skills Development to Enhance Teachers Competencies in Primary Schools, Procedia - Sosial and Behavioral Science.

Katherine, C.\& Debby, K., (2005), Real Word Instructionanl Design Australia, Canada, Mexico, Singapore, Spain, United Kingdom. United State: Thomson Wadsworth

Miles, M. B., \& Huberman, A. M., (1992), Analisis Data Kualitatif terjemahan Rohidi Tj. R., Jakarta: Universitas Indonesia

Peraturan Pemerintah Nomor 19 Tahun 2005 tentang Standar Nasional Pendidikan, Jakarta, Sinar Grafika, 2015.

Setiawan, B., (2017) The Development of Lokal Wisdom-Based Natural Science Module to Improve Science Literation of Students, Jumal Pendidikan IP A Indonesia, Vol. 6 (1)

Siri, R., (2017) Lokal Community Participatory Learning with a Nature Interpretation System: A Case Study in Bang Pong, Sansai District, Chiang Mai, Thailand, Kasetrart Journal of Sosial Science, Vol. 38

\section{Copyright () 2019 Schemata Journal}

Available online at http://journal.uinmataram.ac.id/index.php/schemata 
M. Zaki, Pendidikan Berbasis Keunggulan Lokal pada Madrasab Tsanawiyah di Kota Mataram

Suparman, A., (2011) Desain Instruksional, Jakarta, Pusat Penerbitan Universitas Terbuka.

Trianto, (2008) Mendesain Pembelajaran Kontekstual (Contextual Teaching and Learning) di Kelas, Jakarta, Cerdas Pustaka Publisher

Undang-Undang RI Nomor 20 Tahun 2003 tentang Sistem Pendidikan Nasional, Bandung: Citra Umbara, 2012.

Yaumi, M., (2013) Prinsip-prinsip Desain Pembelajaran, Jakarta: Kencana Prenada, Media Group 
